\title{
USING Rhabditis blumi SUDHAUS AS BIOLOGICAL AGENTS TO CONTROL THE PALP BORER, ARABIAN RHINOCEROS BEETLE, \\ Oryctes agamemnon arabicus
}

\author{
A. M. Tariq \\ Assis. Prof.
}

Instit. Medic. Techn. Al-Mansur, Middle Technical University, Baghdad, Iraq ahmadtarek2001@yahoo.com

\section{ABSTRACT}

This study was aimed to use pathogenicity of entomopathogenic nematodes (EPN) Rhabditis blumi Sudhaus (Nematoda: Rhabditida) against palm borer Arabian Rhinoceros Beetle (ARB), Oryctes agamemnon arabicus was evaluated in the lab. And date palm orchards during 2015 - 2017. In the lab tests, EPN was used against the larvae and adults as a direct spray and as treated food (pieces of fresh tissue of the frond bases) at a rate of $0,500,1000,1500$ Infective Juveniles (IJs) per $\mathrm{mL}$ of $R$. blumi. Results indicated that EPN caused 89\%, $61 \%$ and $25 \%, 20 \%$ mortality when used as a direct spray and as treated food on larvae and adults of ARB, respectively. Results of field experiments showed that injection of $50 \mathrm{~mL}$ per palm tree with a concentration of $1500 \mathrm{IJs} / \mathrm{mL}$ of $R$. blumi inflected about $45.5 \%$ mortality in ARB larvae infesting the tree. Meanwhile, the Population density of ARB larvae reduced to 45.8\%, $59.6 \%$ during the first and second year of treated date palm trees by injection method respectively. The results of this investigation illustrate the possibility of using EPN $R$. blumi as a biocontrol agent for managing borers in date palm orchards under field conditions.

Keywords: biocontrol, palm borers, Oryctes agamemnon arabicus, entomopathogenic nematode, Rhabditis blumi

طارق

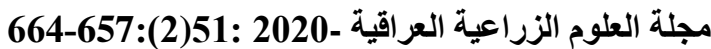

استخدام Rhabditis blumi Sudhaus (Nematoda:Rhabditida كعامل مقاومة احيائي لمكافحة خنفساء وحيدة Oryctes Agamemnon arabicus القرن العربية

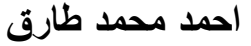

$$
\begin{aligned}
& \text { استاذ مساعد } \\
& \text { المعهد التقني الطبي /المنصور ,الجامعة التقتية الوسطى ,بغداد ,العرلق . }
\end{aligned}
$$

المستخلص

الحفارات من الآفات الخطيرة على النخيل في العرلق والبلان الأخرى التي يزرع فيها نخيل التمر تسبب هذه الآقات ضرا بالغا في أثجار النخيل وتقلل انتاجها كما ونوعا وتسبب ضعف في الجذع مما يؤدي الى موت النظله وانكساره .تم تقييم فاعلية النيماتودا الممرضة

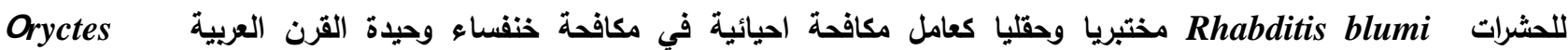
Agamemnon arabicus الغذاء ( قطع طرية من كرب النخيل ) , وقد استعملت النيماتودا بالتراكيز 0 , 500 , 1000 , 1500 طور معدي ( IJs ) في كل مل.

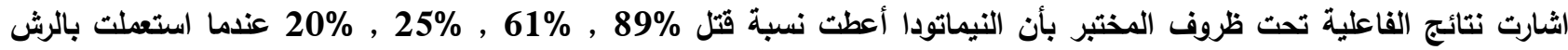
المباشر وفي معاملة الغذاء على اليرقات والبالغات على التوالي ـ اما تجارب الفاعلية الحقيقية فقد أعطت فاعلية قتل في اليرقات 45.5 \% عندما استعملت بتركيز 1500 طور معدي ( IJs ) لكل مل. كما شارت النتائج حصول انخفاض في الكثافة السكانية ليرقات خنفساء وحيدة القرن العربية بنسبة 45.5\% , 59.6\% وذلك خلال السنة الأولى والثانية بعد معاملة النخيل على التوالي ,من النتائج المتحصل فئل عليها يمكن ان تخدم في استعمال النيماتودا Rhabditis blumi كعامل مكافحة احيائية في برنامج إدارة حفارات النخيل في بساتين نخيل التمر عند الظروف الحقلية.

كلمات مفتاحية: المقاومة الحيوية, حفار النخيل, Oryctes agamemnon arabicus , النيهاتود/ الممرضة للحشرات, Rhabditis

*Received:22/7/2019, Accepted:8/10/2019

blumi 


\section{INTRODUCTION}

Palm borers, especially Oryctes spp. are considered as an economically important insect pest of date palm trees in Iraq and most adapted to climatic conditions of the region (12 and 4). Arabian Rhinoceros Beetle (ARB), Oryctes agamemnon arabicus causes severe damages to the bases of fronds and bunches making long tunnels inside the tissue, which are acting as weakening and breaking factors for these parts (13). Many control methods have been used through different application methods: spray, drench and injection $(5,88$, and 11) against to date palm pests. Khalaf (14) Reported that the application of thiamethoxam and imidacloprid against ARB larvae resulted in $85.8 \%, 100 \%$ mortality in injection method compared with $75 \%, 80 \%$ in the drench method respectively.Khudair (15) Tested locally isolated entomopathogenic fungi Metarhizium anisopliae and Beauveria bassiana against ARB larvae and reported a high mortality rate among larvae reaching up to $100 \%$ after 29 days of treatment under lab conditions. Entomopathogenic nematodes will only be widely used as pest control products when they become available on demand by the different clients, commercial growers and small farmers (16). Rhabditid nematodes are generally recognized as bacterivores and often associated with invertebrates, their relationship with invertebrates is known as necromancy, which means waiting for the death host $(6,20$, 23, 28 and 26). Khalaf (14) Tested entomopathogenic nematodes (EPN), Rhabditis blumi, and the entomopathogenic fungi (EPF), Beauveria bassiana as biocontrol agents against larvae and adults of ARB, $O$. agamemnon arabicus. Biological control potentials of $R$. blumi against 5 coleopteran species and 5 lepidopteran species was evaluated by Park (19). This study aimed to investigate the efficacy of EPN, Rhabditis blumi as entophytic biocontrol agents against palm borers, Oryctes spp. especially ARB, $O$. agamemnon arabicus under laboratory and field conditions. Another objective was to investigate the feasibility of application and persistent in date palm orchards.

\section{MATERIALS AND METHODS}

Borers and nematodes cultures: Samples of ARB O. agamemnon arabicus were obtained from the lab. Colony reared on natural foods (palm tissues, fresh frond bases pieces) at $25 \pm 2^{\circ} \mathrm{C}$, complete darkness and $65 \%$ relative humidity in the IPM Center, Directorate of Agricultural Research, and Ministry of Science and Technology (14). R. blumi was obtained from the lab. Colony reared on larvae of wax moth Galleria mellonella in labs of IPM center (14).

\section{Laboratory experimental treatments}

The laboratory trials were conducted in Biological Control Dept. of IPM Center. Laboratory experiments included using four concentrations $(0,500,1000$ and 1500 IJs per $\mathrm{mL}$ ) of $R$. blumi as direct spray on larvae and adults of ARB or mixed with their food (pieces of frond bases tissue). Fresh food pieces were added regularly through the period of treatment to keep enough fresh food to the larvae. Five replicates, 6 larvae/rep as larval treatment and four replicates, 5 adults/rep as adult's treatment were used for each treatment as for laboratory experiments. Larval and adults mortalities were counted in all treatments after 24, 72, 96 and 120 hours of treatment.

\section{Field experimental treatments}

Field experiments, injection of $50 \mathrm{~mL}$ solution of EPN $1500 \mathrm{IJ} / \mathrm{mL}$ was done through tree trunk using $50 \mathrm{~mL}$ syringes after drilling holes with a brad point drill- bit (diameter, $20 \mathrm{~mm}$ and length, 200mm) $1 \mathrm{~m}$ above the ground level (Fig. 1-A, B). The same number of trees were left as control treatment in each orchard. Five replicates (trees) were used for each treatment. Larvae of ARB in trees crown were collected after four weeks of injection EPN, dead and live larvae were counted in each treatment and kept in plastic containers (Fig.1C). Also, fresh frond bases tissues were collected and healthy larvae of G. mellonella were added to test if it contains EPN, R. blumi in each treatment. Samples of tissue were taken after 4 weeks of treatment for examination and to explore the presence and movement of EPN through plant tissue. Larval mortalities that infected by EPN in each treatment were counted.

Efficacy and persistent of
entomopathogenic nematode Rhabditis
blumi in date palm orchards: Efficacy and
persistent of EPN $R$. blumi were studied in


two date palm orchards, the first one was untreated (control) orchard, the second orchard was treated with EPN mixed in $50 \mathrm{~mL}$ at a concentration of $1500 \mathrm{IJs}$ by used injection methods in ten tree trunk. EPN distribution and efficacy in reduction of ARB Larvae population density were counted by calculating larvae in ten palm tree Brem variety in each orchard before treatment and during the first and second year after treatment.

\section{Experimental design and data analysis}

The experimental designs implemented were complete randomized design and randomized complete block design with four replicates . Genstat program was implied in statistical analysis and determine the significances efficacies. Henderson-Tilton, s formula (1955) (10) was used to calculate corrected mortality efficacies\% on larval and adults ARB treated with EPN in lab treatments, while SchneiderOrelli, s formula (1981) (10) was applied for measuring efficacies of the EPN tested on $\mathrm{ARB}$ at field treatment.

\section{RESULTS AND DESCUSSION}

Results in Table 1 indicates that the mortality percentage of ARB larvae after direct spray under laboratory conditions with EPN R. blumi revealed that highest concentration (1500 $\mathrm{IJs} / \mathrm{mL}$ ) caused the highest percentage of mortality $89 \%$ after $120 \mathrm{hr}$., while the lower concentrations of 1000 and $500 \mathrm{IJs} / \mathrm{mL}$ recorded mortality of $79 \%$ and $57 \%$ respectively. Meanwhile, mortalities reached $50 \%, 54 \%$ and $61 \%$ at concentrations of 500 , 1000 and $1500 \mathrm{IJs} / \mathrm{mL}$ respectively in experiments when EPN was mixed with larval food (table1). 
Table 1. Effect of entomopathogenic nematode Rhabditis blumi as a biocontrol agent against palm borer, Oryctes agamemnon arabicus larvae under laboratory conditions

\begin{tabular}{|c|c|c|c|c|c|c|c|c|c|c|c|c|c|c|}
\hline \multirow{3}{*}{$\begin{array}{l}\text { Treatment } \\
\text { method }\end{array}$} & \multirow{3}{*}{$\begin{array}{l}\text { Concentratio } \\
\text { n of } \\
\text { R. blumi } \\
\text { (IJs/mL) }\end{array}$} & \multirow{3}{*}{$\begin{array}{l}\text { Total of } \\
\text { larvae } \\
\text { treated }\end{array}$} & \multicolumn{12}{|c|}{ \% Corrected mortality(accumulation) After(hr) } \\
\hline & & & & 24 & & & 72 & & & 96 & & & 120 & \\
\hline & & & $\begin{array}{l}\text { Larva } \\
\text { dead }\end{array}$ & $\begin{array}{c}\% \\
\text { mortality }\end{array}$ & $\begin{array}{c}\% \\
\text { Efficacy }\end{array}$ & $\begin{array}{l}\text { Larva } \\
\text { dead }\end{array}$ & $\begin{array}{c}\% \\
\text { mortality }\end{array}$ & $\begin{array}{c}\% \\
\text { Efficacy }\end{array}$ & $\begin{array}{c}\text { Larva } \\
\text { dead }\end{array}$ & $\begin{array}{c}\% \\
\text { mortality }\end{array}$ & $\begin{array}{c}\% \\
\text { Efficacy }\end{array}$ & $\begin{array}{c}\text { Larva } \\
\text { dead }\end{array}$ & $\begin{array}{c}\% \\
\text { mortality }\end{array}$ & $\begin{array}{c}\% \\
\text { Efficacy }\end{array}$ \\
\hline \multirow{5}{*}{ Direct spray } & & & & & & & & & & & & & & --- \\
\hline & $\begin{array}{l}\text { Control } \\
\text { (water) }\end{array}$ & 30 & $\mathbf{0}$ & --- & --- & $\mathbf{0}$ & --- & -- & 1 & --- & --- & 2 & --- & --- \\
\hline & 500 & 30 & 13 & 43 & 43 & 17 & 57 & 57 & 17 & 57 & 55 & 18 & 60 & 57 \\
\hline & 1000 & 30 & 21 & 70 & 70 & 23 & 77 & 77 & 23 & 77 & 76 & 24 & 80 & 79 \\
\hline & 1500 & 30 & 25 & 83 & 83 & 26 & 87 & 87 & 27 & 90 & 89 & 27 & 90 & 89 \\
\hline \multirow[t]{4}{*}{$\begin{array}{l}\text { Treated diet } \\
\text { (frond bases) }\end{array}$} & $\begin{array}{l}\text { Control } \\
\text { (water) }\end{array}$ & 30 & $\mathbf{0}$ & --- & --- & $\mathbf{0}$ & --- & --- & 1 & --- & --- & 1 & --- & ---- \\
\hline & 500 & 30 & 15 & 50 & 50 & 15 & 50 & 50 & 16 & 53 & 52 & 16 & 53 & 50 \\
\hline & 1000 & 30 & 14 & 47 & 47 & 15 & 50 & 50 & 17 & 57 & 55 & 17 & 57 & 54 \\
\hline & 1500 & 30 & 16 & 53 & 53 & 16 & 53 & 53 & 19 & 63 & 62 & 19 & 63 & 61 \\
\hline
\end{tabular}

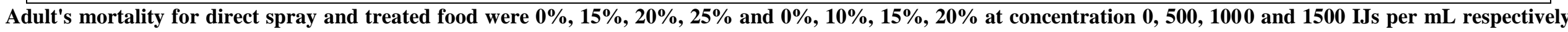
(Table 2).

Table 2. Effect of entomopathogenic nematode Rhabditis blumi as a biocontrol agent against palm borer, Oryctes agamemnon arabicus adults under laboratory conditions.

\begin{tabular}{|c|c|c|c|c|c|c|c|c|c|c|c|c|c|c|}
\hline \multirow{3}{*}{$\begin{array}{l}\text { Treatmen } \\
\text { t method }\end{array}$} & \multirow{3}{*}{$\begin{array}{c}\text { Concentratio } \\
\text { n of } \\
\text { R. blumi } \\
\text { (IJs/mL) }\end{array}$} & \multirow{3}{*}{$\begin{array}{l}\text { Total of } \\
\text { adults } \\
\text { treated }\end{array}$} & \multicolumn{12}{|c|}{ \% Corrected mortality(accumulation) After(hr) } \\
\hline & & & & 24 & & & 72 & & & 96 & & & 120 & \\
\hline & & & $\begin{array}{l}\text { adult } \\
\text { dead }\end{array}$ & $\begin{array}{c}\% \\
\text { mortality }\end{array}$ & $\begin{array}{c}\% \\
\text { Efficacy }\end{array}$ & $\begin{array}{l}\text { adult } \\
\text { dead }\end{array}$ & $\begin{array}{c}\% \\
\text { mortality }\end{array}$ & $\begin{array}{c}\% \\
\text { Efficacy }\end{array}$ & $\begin{array}{l}\text { adult } \\
\text { dead }\end{array}$ & $\begin{array}{c}\% \\
\text { mortality }\end{array}$ & $\begin{array}{c}\% \\
\text { Efficacy }\end{array}$ & $\begin{array}{l}\text { adult } \\
\text { dead }\end{array}$ & $\begin{array}{c}\% \\
\text { mortality }\end{array}$ & $\begin{array}{c}\% \\
\text { Efficacy }\end{array}$ \\
\hline \multirow[t]{4}{*}{$\begin{array}{l}\text { Direct } \\
\text { spray }\end{array}$} & $\begin{array}{l}\text { Control } \\
\text { (water) }\end{array}$ & 20 & $\mathbf{0}$ & -- & -- & $\mathbf{0}$ & -- & -- & $\mathbf{0}$ & -- & -- & $\mathbf{0}$ & -- & -- \\
\hline & 500 & 20 & $\mathbf{0}$ & $\mathbf{0}$ & $\mathbf{0}$ & $\mathbf{0}$ & $\mathbf{0}$ & $\mathbf{0}$ & 3 & 15 & 15 & 3 & 15 & 15 \\
\hline & 1000 & 20 & 1 & 5 & 5 & 3 & 15 & 15 & 4 & 20 & 20 & 4 & 20 & 20 \\
\hline & 1500 & 20 & 3 & 15 & 15 & 5 & 25 & 25 & 5 & 25 & 25 & 5 & 25 & 25 \\
\hline \multirow{4}{*}{$\begin{array}{c}\text { Treated } \\
\text { diet } \\
\text { (frond } \\
\text { bases) }\end{array}$} & $\begin{array}{l}\text { Control } \\
\text { (water) }\end{array}$ & 20 & 0 & --- & --- & 0 & --- & --- & 0 & --- & ---- & 0 & --- & ---- \\
\hline & 500 & 20 & 0 & 0 & 0 & 2 & 10 & 10 & 2 & 10 & 10 & 2 & 10 & 10 \\
\hline & 1000 & 20 & 2 & 10 & 10 & 2 & 10 & 10 & 3 & 15 & 15 & 3 & 15 & 15 \\
\hline & 1500 & 20 & 3 & 15 & 15 & 3 & 15 & 15 & 4 & 20 & 20 & 4 & 20 & 20 \\
\hline
\end{tabular}


Field efficacy results indicated that the mortality percentage of ARB larvae after trunk injection with $50 \mathrm{~mL}$ in concentration $1500 \mathrm{IJs}$

Table.3 Effect of entomopathogenic nematode, Rhabditis blumi as biocontrol agents against on palm borer, Oryctes agamemnon arabicus larvae under field conditions

\begin{tabular}{|c|c|c|c|c|}
\hline \multirow{3}{*}{$\begin{array}{c}\text { Treatment } \\
\text { (Trunk injection) }\end{array}$} & \multicolumn{4}{|c|}{ Number of larvae per five trees ( in tree crown only) } \\
\hline & \multirow[t]{2}{*}{ Before treatment } & \multicolumn{2}{|c|}{ After 4 weeks of treatment } & \multirow{2}{*}{$\begin{array}{c}\text { \%corrected } \\
\text { mortality }\end{array}$} \\
\hline & & Life & Dead & \\
\hline Control & Unknown & 35 & $\mathbf{0}$ & --- \\
\hline $\begin{array}{l}50 \mathrm{~mL} \text { ( } 1500 \mathrm{IJs} \\
\text { per } \mathrm{mL} \text { ) per tree }\end{array}$ & Unknown & 12 & $\begin{array}{c}10 \text { (dead and } \\
\text { new place of } \\
\text { larva) }\end{array}$ & 45.5 \\
\hline
\end{tabular}

The use of EPN R. blumi in date palm orchards as a biocontrol agent against Oryctes larvae caused a reduction in population density reached $45.8 \%$ and $59.6 \%$ after one month and during the second year of treatment respectively (Table 4).

Table 4. Distribution and efficacy of entomopathogenic nematode Rhabditis blumi in date palm orchards in Alsweera in Middle of Iraq

\begin{tabular}{|c|c|c|c|c|c|}
\hline \multirow{3}{*}{$\begin{array}{l}\text { Treatment } \\
\text { (orchard) }\end{array}$} & \multicolumn{5}{|c|}{ Number of larvae per ten tree in crown tree only (Brem variety) } \\
\hline & \multirow{2}{*}{$\begin{array}{c}\text { Before } \\
\text { treatment } \\
\text { Life larva }\end{array}$} & \multicolumn{2}{|c|}{$\begin{array}{c}\text { During the first year after } \\
\text { treatment }\end{array}$} & \multicolumn{2}{|c|}{$\begin{array}{c}\text { During the second year } \\
\text { after treatment }\end{array}$} \\
\hline & & Life larva & $\begin{array}{c}\% \\
\text { Reduction in } \\
\text { population }\end{array}$ & $\begin{array}{c}\text { Life } \\
\text { larva }\end{array}$ & $\begin{array}{c}\% \\
\text { Reduction in } \\
\text { population }\end{array}$ \\
\hline \multicolumn{6}{|l|}{ Control Orchard No } \\
\hline 1 & 120 & 131 & --- & 115 & --- \\
\hline Without Nematode & & & & & \\
\hline Orchard No.2 & 93 & 55 & 45.8 & 36 & 59.6 \\
\hline
\end{tabular}

Results of field studies revealed that there was an acceptable efficacy of applying local isolate of EPN R. blumi (isolated locally from Iraqi date palm orchards ecosystem) as biocontrol agents. The EPN $R$. blumi can persist habitat causing more reduction in the population density of ARB, O. agamemnon arabicus larvae. In addition, results indicated that the EPN, R. blumi solution could translocate through date palm tissue after injection in the trunk. Park (19) Reported that EPN R. blumi against major cruciferous insect pests and evaluated pathogenicity in lab and greenhouse and showed that EPN caused high mortality rate in larvae. Entomopathogenic nematodes have certain advantages over chemical as control agents; it's a non-polluting agent and thus environmentally safe and acceptable (9). There are many reports for rhabditid nematodes causing mortality of various invertebrates' species: beetles, termite, millipede and rice yellow stem borer $(1,7,22$,
23, and 25). (2, 3,11,24 and 27) they found that the Infective Juveniles of rhabditid nematodes enter an invertebrate, remain until it is dead, and complete their development by feeding on bacteria growing inside the cadaver of insect, and it usually possesses some attributes of a potential biological control agents, such as short life cycle, easy culture condition with bacteria, high fecundity and virulence, and good association with invertebrate pathogenic bacteria. EPN Rhabditis blumi showed significant mortality against Arabian rhinoceros beetle Oryctes agamemnon arabicus, but the mortality rate of larvae was higher than that of adults in lab trails at direct spray or treated food. When EPN was mixed with $50 \mathrm{ml}$ of water at a concentration of $1500 \mathrm{IJs} / \mathrm{ml}$ and injected in reported among ARB larvae. However, dispersal and efficacy were increased in treated orchards after one year of treatment. the trunk, a moderate mortality rate was 


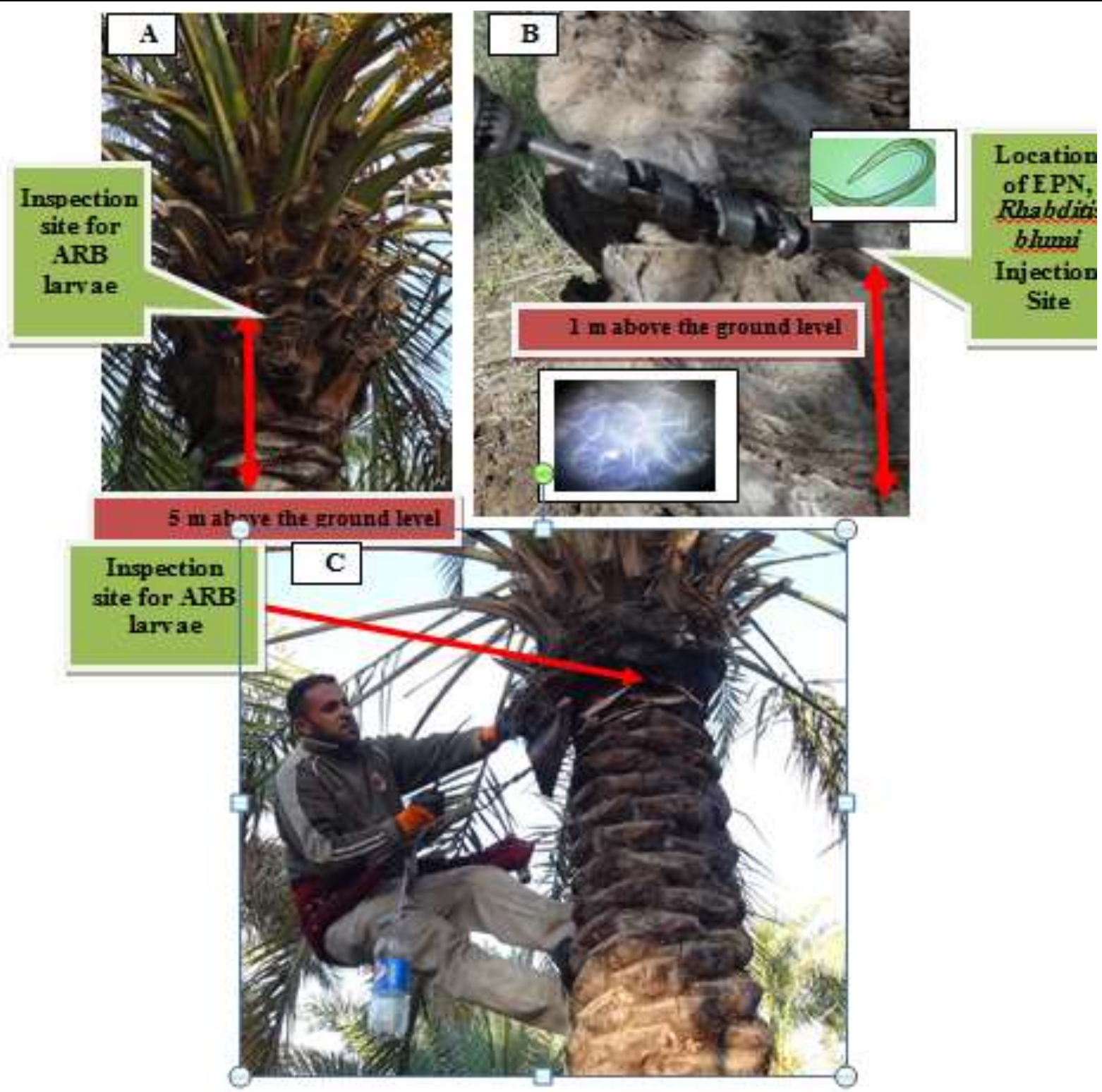

Figure 1. (A)- Inspection site for ARB larvae, (B) - location of EPN Injection site, (C)Inspection of palm tree crown for collecting ARB larvae.

\section{REFERENCES}

1. Abood, S.M., M.R. Abood and A.A. Jasim. 2018. Manufacturing and testing of date palm vibration motorized frauds cutter. Iraqi Journal of Agricultural Sciences -1028:49(3):763- 73 1

2. Abood,I.D. and H.SH. Yasien .2016. Detection resistance genes of root knot nematode $\mathrm{Mi}$ in some of pure lines of tomato indeterminate growth. Abood, I.D. Iraqi Journal of Agricultural Sciences - 47(5):13211327

3. Al- sahaf, F.H. , Abed Y.M. , Saleh , F.F. , and H.S.M. Khierallah ,. 2017. Influence of spraying by some plant growth regulators on date palm salt tolerance enhancement... The Iraqi Journal of Agricultural Sciences - 48(1): 236-241,2017
4. Al_shali, M.A.M, Al_kalyani, A.I.N, Dayinna and K.Yardi 2019 Can Industrialization affect heavy metals bio concentration in date palm tree farms in the Sultanate of Oman. Iraq Journal of Agricultural Sciences. 2019:50 (Special Issue) : 152-172

5. Al-Jboory, I. J., A. I. Al.Sammariae, J. F. Whaib and W. A. Ahmed, 2001. Evaluation of thiamethoxam in a different application technique to control Dubas bug Ommatissus lybicus. J. Arab Pl. Prot., 19:47- 53

6. Blaxter, M. L., P. De Ley, J. R. Gary, L. X. Liu, P. Scheldemman and A. Vierstraete. 1998. A molecular evolutionary framework for the phylum Nematoda. Nature, 392: 71-75

7. Carta, L. K. and J. C. Osbrink. 2005. Rhabditis rainai n. sp. (Nematoda: Rhabditida) 
associated with the Formosan subterranean termite, Coptotermes formosanus (Isoptera; Rhinotermitidae). Nematology, 7: 863-879

8. Felsot, S. A, 2002. Application of New Generation Systemic Insecticide Through Drip Irrigation Systems: Case Study With Imidacloprid. Research and Extension regional water quality conference, $\mathrm{pp}: 3$

9. Georgis, R. 1990. Formulation and Application Technology in Gaugler, R., H. K. Kaya, eds. Entomopathogenic Nematodes in Biological Control. Boca Raton. FL: CRC Press. , pp: 173- 191

10. Henderson, C. F. and E. W. Tilton. 1955. Tests with acaricides against the brow wheat mite, J. Econ. Entomol 48:157-161

11. http:// www. researchgate. net/ publication/ 228425523. Accessed on 19 Jan. 2017. Timmeren, S.V., C.J. Wise and R. Isaacs, 2012. Soil application of neonicotinoid insecticide for control insect pests in wine grape, published online in Wiley online library. Pest Mang. Sci., 68:537-542

12. Khalaf M. Z., A. K Shbar., M. H. AlSeria, R. A. Sami, and F. H. Naher 2011. Some aspects of biology and control methods of fruit stalk borer Oryctes elegans Prell (Coleoptera: Scarabaeidae). Journal of Agricultural Science and Technology a 1:142147

13. Khalaf M. Z., and A. A Al-Taweel,. 2015. Palm borers in Iraqi environment: speciesdamages- methods of control. J. of the Blessed Tree, 07:54-64

14. Khalaf, M. Z., H. F. Alrubaei, F. H. Naher and M. Dh. Jumaa. 2016. Biological control of the date palm tree borers, (Coleoptera:

Scarabaidae: Dynastinae. Book of Proceedings VII International Scientific Agriculture Symposium (Agrosym2016). Jahorina, Bosnia and Herzegovina, October 06-09, 1561-1566

15. Khudhair, M. W., M. Z. Khalaf, H. F. Alrubeai A. K. Shbar, B. S Hamad. and H. S. Khalaf 2015. Evaluating the virulence of Metarhizium anisopliae (Deuteromycotina: Hyphomycetes) and Beauveria bassiana (Ascomycota: Hypocreales) isolates to Arabian rhinoceros beetle, Oryctes agamemnon arabicus. J. of Entomological and Acarological Research 47: 117-122
16. Mwaniki, S. W., J. H. Nderitu, F. Olubayo and J. W. kimenju. 2013. Mass production of entomopathogenic nematodes using Silkworm, Bombyx mori L. for management of key agricultural pests. $12^{\text {th }}$ KARI Scientific Conference Proceedings 2010: 759-763

17. Padmakumari, A. P., J. S. Prasas, G. Katti and M. Sankar. 2007. Rhabditis sp. (Oscheius sp.), abiocotrol agent against rice yellow stem borer, Scirpophaga incertulas. Inian J. Plant protection. 35: 2-28

18. Park, H. W., H. H. Kim, S.H. Youn, T. S. Shin, A. L. A. L. Bilgrami, M. R. Cho and C. S. Shin. 2012. Biological control potentials of insect-parasitic nematode Rhabditis blumi (Nematoda: Rhabditida) for major cruciferous vegetable insect pests. Applied Entomol. Zool. 47: 389-397

19. Park, H. W., Kim, M. R. Cho, T. J. Kang, S. J. Ahu, S. W. Jeon, and A. L. Bilgrami. 2012. Evaluation of biological potentials of Rhabditis blumi (Nematoda: Rhabditida) against 10 insect species. Journal Information service System 37:235-239

20. Park, H. W., Y. O. Kim, J. Ha, S. H. Youn, H. H. Kim, A. L. Bilgrami and C. S. Shin. 2011. Effects of associated bacteria on the pathogenicity and reproduction of the insect parasitic nematode Rhabditis blumi (Nematoda: Rhabditida). Can. J. Microbiol 57:750-758

21. Püntener, W. 1981. Manual for Field Trials in Plant Protection $2^{\text {nd }}$. ed. Agricultural Division, Ciba-Geigy Limited ,pp.37

22. Richter, S. 1993. Phoretic association between between the dauer juveniles os Rhabditis stammeri and life history stages of the burying beetle Nicrophorus vespilloides (Coleoptera: Silphidae). Nematologica, 39: $346-355$

23. Schulte, F 1989. The association between Rhabditis nectomena Sudhaus and Schutle, 1989 (Nematoda: Rhabditidae) and native and introduced millipedes in South Australia. Nematologica, 35: 82-89

24. Shblawy, L. M. and Al-Jorany R.S. 2018. Sunn pest species and its hibernation sites in Diyala Governorate / IRAQ. Iraqi Journal of Agricultural Sciences -49(6):0002-0088

25. Smart, G. C. and K. B. Nguyen. 1994. Rhabditis Pheropsophi (Rhabditida: Rhabditidae). J. Nematology. 26: 19-24 
26. Stock, S. P., A. M. Caiceda and P. A. and Rhabditis caulleryi Manupas. Calatayud. 2005. Rhabditis (Oscheius) Nematologica, 35: 15-24

Colombiana (Nematoda: Rhabditidae), a 28. Wilson, M. J., D. M. Glen, S. K. George, necromenic associate of the subterranean and R. C. Butler. 1993. Mass cultivation and burrower bug Cyrtomenus bergi (Hemiptera: Cydnidae) from Cauca Valley, Colombia. Nematology, 7: 417-373

27. Sudhaus, W. and F. Schulte. 1989. Rhabditis necromena (Nematoda:Rhabditidae) from South Australian diplopoda with notes on its sibling Rhabditis myriophila poinar, 1986 storage of Rhabditid Nematode Phasmarhabditis hermaphrodita, a biocontrol agent for slige. Biocontrol Sci. Technol. 3: 513-521. 